Proceedings

\title{
Energy Service Business Models and Entrepreneurial Skills: Identifying Models and Patterns ${ }^{\dagger}$
}

\author{
Ruth Mourik ${ }^{1, *}$ and Renske Bouwknegt ${ }^{2}$ \\ 1 Duneworks, 5625 NN Eindhoven, The Netherlands \\ 2 Ideate, 3812 BH Amersfoort, The Netherlands; renske@ideate.nl \\ * Correspondence: ruth.mourik@duneworks.nl; Tel.: +31-625-075-760 \\ + Presented at the Sustainable Places 2020, Online, 28-30 October 2020; \\ Available online: https://www.sustainableplaces.eu/.
}

Published: 12 January 2021

\begin{abstract}
Given the important role entrepreneurship can play in the energy transition, in this paper we set out to better understand how more radical business models and entrepreneurial journeys are shaped by the institutional context and other system factors within which they aim to scale up. The aim was to explore research questions related to how more radical business models and services, and the entrepreneurs developing them, deal with the system around them, and what the system conditions are that either limit or facilitate the flourishing of those energy services that are potentially strong contributors to the energy transition because they challenge the existing system.
\end{abstract}

Keywords: new business models; institutional work; flexibility services; entrepreneurship; transition; system change

\section{Introduction}

With all the attention the energy transition attracts nowadays, one could easily imagine that doing business in this market is an easy ticket to success. Sadly, this is not the case. In reality, only a relatively small group of entrepreneurs is able to take advantage of this sense of urgency. Of course, there are many explanations for this. The complexity of climate change can hardly be underestimated, nor can the struggle to create solutions to solve the problem of market uptake. One thing is certain: entrepreneurs play a key role in the energy transition. After analyzing dozens of business models, conducting at least as many interviews with energy entrepreneurs, reading up on relevant theories, and researching the characteristics of the markets in which they operate (as part of the annex "Energy Business Models and Systems" under the Technology Collaboration Programme "User-Centered Energy Systems" by the International Energy Agency), we conclude that those entrepreneurs that manage to build strong business models for more radical energy services demonstrate the ability to align many important elements, creating agency. However, many entrepreneurs that could make an important contribution to the energy transition do not master that agency and need help from multiple system stakeholders. However, the current energy transition market is too product-centered to be able to offer that support and needs to change to increase or accelerate the uptake of energy solutions.

\section{Materials and Methods}

Previous research on the apparent lack of market uptake of energy efficiency found that entrepreneurs that adopt a service-oriented business model and have clear servitization skills [1]. These service-oriented entrepreneurs prove to be often more successful at creating a market for their business model and service and at growing their market share and scaling up [2,3]. Given the 
important role entrepreneurship can play in the energy transition, we set out to better understand how the uptake of more radical business models and services can benefit from a servitization approach as well. In the framework of the annex "Energy Business Models and Systems" of the Users Technology Collaboration Programme by the International Energy Agency (IEA), we explored these questions with a research team from four countries: the Netherlands (coordinator), Australia, Ireland and Sweden. The research was based on a dynamic, qualitative research methodology involving desk research, a literature study, interviews and case studies.

\section{Results}

Our research found that only a few radical services and business models are successful. Mostly, when these more radical business models and services challenge the existing system, by requiring new technological, policy, institutional or cultural constellations to be able to scale up, very often they are not successful at shaping these changes. Instead, these business models and services need to adjust to survive, tone their level of innovation down and become more business-as-usual, and as such the potential contribution they could make to the energy transition has not materialized [4]. Interestingly enough, the entrepreneurs we worked with listed similar types of barriers and pitfalls to service-oriented business models that all can be seen as systemic barriers, barriers that are the result of the current state of the system: a system that is transitioning towards a greener, more inclusive, sustainable energy sector. We categorized the listed barriers and failures into the following categories: complexity, uncertainty, technocracy, organized irresponsibility, and contestation. We argue that the accumulation of the system pitfalls listed above causes inertia of the transition process.

However, we also witnessed a different kind of outcome for some of the potentially transformative business models and energy services. Despite many setbacks, several entrepreneurs were successful in breaking this pattern of reverting to business as usual, abandoning the potentially transformative elements. These entrepreneurs are, unlike their peers, capable of delivering business models and services that do contribute to the energy transition. What characterizes these entrepreneurs, or entrepreneurial teams (some of these are consortia or energy communities), is first of all that these entrepreneurs go beyond creating a service supporting business model: they create a transition supporting business model to deliver a transformative innovation as a service.

A second characteristic of these entrepreneurs has to do with their interaction with the system. Many of them are very capable of turning systemic challenges into opportunities. They use the collectively experienced system failure as the raison d'être and legitimation for their business model. Some of these entrepreneurs even go a step further. They develop their service and business model with the explicit aim to contribute to changing policies or regulations, or answering questions, contributing to discourses that need to be concluded for a step to be taken at the institutional level, and are successful at doing so. This type of entrepreneurship is called institutional entrepreneurship [5-9].

\section{Discussion and Conclusions}

If we want to accelerate the energy transition and overcome inertia, we need many more energy services and business models and thus many more entrepreneurs and initiatives to be successful at contributing to the transition. One way of approaching this is of course to increase the number of savvy or institutional entrepreneurs. Training and developing capabilities and adjusting business models towards more service and transition orientation will certainly help. However, apart from the fact that the transition capabilities are only transferrable to others to a certain extent, despite their success, these entrepreneurs still have to operate in a system that falls short in supporting them as well as their less savvy colleagues and competitors. Developers of energy services need to be able to operate in a system that supports them and their transformative or transition-supporting service much more effectively. At the moment this system is not yet "fit to serve" energy services. The question that emerges and that we will explore further is how the system could or should be adjusted to become less product-focused and more service-supporting. 
Author Contributions: Both authors were equally involved in conceptualization, methodology, validation, formal analysis, investigation and writing-original draft preparation. All authors have read and agreed to the published version of the manuscript.

Funding: This research was funded by Swedish, Dutch, Irish and Australian participants in the users' technology Collaboration Programme by the International Energy Agency.

Acknowledgments: We would like to acknowledge the enormous support given by the national experts involved in this project: Lotta Bangens, Tony Fullelove, Matthew Kennedy and Jo Southernwood.

Conflicts of Interest: The authors declare no conflict of interest.

\section{References}

1. Janssen, M.J.; Castaldi, C. Services, innovation, capabilities, and policy: Toward a synthesis and beyond. Sci. Public Policy 2018, 46, 863-874.

2. Mourik, R.M.; Castaldi, C.; Huijben, J.C.C.M. Business models for energy efficiency services: Four archetypes based on user-centeredness and dynamic capabilities. In Business Models for Sustainability Transformation; Aagaard, A., Lüdeke-Freund, F., Wells, P., Eds.; Palgrave MacMillan: London, UK, 2021, forthcoming.

3. Tolkamp, J.; Huijben, J.C.C.M.; Mourik, R.M.; Verbong, G.P.J.; Bouwknegt, R. User-centred sustainable business model design: The case of energy efficiency services in the Netherlands. J. Clean. Prod. 2018, 182, 755-764.

4. Mourik, R.M.; Breukers, S.C.; van Summeren, L.F.M.; Wieczorek, A.J. The impact of the institutional context on the potential contribution of new business models to democratising the energy system. In Energy and Behaviour. Towards a low Carbon Future; Lopes, M., Henggeler, A.C., Janda, K., Eds.; Elsevier: Amsterdam, The Netherlands, 2019.

5. DiMaggio, P. Interest and agency in institutional theory. In Institutional Patterns and Organizations: Culture and Environment (3-21); Zucker, L., Ed.; Ballinger Publishing: Cambridge, UK, 1988.

6. Jolly, S.; Spodniak, P.; Raven, R. Institutional entrepreneurship in transforming energy systems towards sustainability: Wind energy in Finland and India. Energy Res. Soc. Sci. 2016, 17, 102-118.

7. Garud, R.; Hardy, C.; Maguire, S. Institutional Entrepreneurship as Embedded Agency: An Introduction to the Special Issue. Manag. Stud. 2007, 28, 957-969.

8. Heiskanen, E.; Kivimaa, P.; Lovio, R. Promoting sustainable energy: Does institutional entrepreneurship help? Energy Res. Soc. Sci. 2019, 50, 179-190.

9. Mahzouni, A. The role of institutional entrepreneurship in emerging energy communities: The town of St. Peter in Germany. Renew. Sustain. Energy Rev. 2019, 107, 297-308.

Publisher's Note: MDPI stays neutral with regard to jurisdictional claims in published maps and institutional affiliations.

(C) 2021 by the authors. Licensee MDPI, Basel, Switzerland. This article is an open access article distributed under the terms and conditions of the Creative Commons Attribution (CC BY) license (http://creativecommons.org/licenses/by/4.0/). 